\author{
V.A. Yanchuk ${ }^{1}$ (D) , G.S. Sultanbayeva ${ }^{2}$ \\ E.S. Sultanbayeva ${ }^{3}$ (iD), O.P. Lozhnikova ${ }^{2,4}$ \\ ${ }^{1}$ Belarusian State University, Belorussia, Minsk, \\ ${ }^{2,4} \mathrm{Al}$-Farabi Kazakh National University, Kazakhstan, Almaty, \\ ${ }^{3}$ Agency «Khabar», Kazakhstan, Almaty, \\ 1e-mail: yanchuk1303@gmail.com \\ 2e-mail: Gulmira.Sultanbayeva@kaznu.kz \\ ${ }^{3}$ e-mail: sultanbayeva.elmira@gmail.com \\ ${ }^{4}$ e-mail: Olga.Lozhnykova@kaznu.kz
}

\title{
INTELLECTUAL CAPITAL AS THE BASIS OF KNOWLEDGE SOCIETY DEVELOPMENT
}

The article is devoted to the problems of the development of a knowledge society. The formation of an "intellectual nation" is a way of modernizing society in the 21 st century, when creative individuals become the main source of development. "Intellectual nation project" should consider three potential points: creation of new solutions, technologies and innovations; information revolution; spiritual education of youth. Today Kazakhstan has enough features to take its rightful place in the sphere of training specialists competitive on the world stage.

The purpose of this article is the production of fixed capital and the highest value - an individual, who is not only a professional, but also carries qualities and properties of his spiritual and moral personality.

The article carried out a systematic and comparative analysis of the works of outstanding researchers who conducted research in the field of intellectual investments, intangible values, economic freedom, political freedom, mass communication and public interests, political discourse and metaphor, as well as analysis, discussion and evaluation of ways to form a national Kazakhstan's potential.

To increase the intellectual potential of Kazakhstan, it is necessary to create a knowledge society. Prerequisites contributing to this, consider increasing scientific and innovative potential, increasing access to education for the population, increasing access to informational equality for citizens.

When working on the study, the authors applied the content analysis method in the theoretical part and the questionnaire method. The scientific novelty of this study is to develop recommendations for optimizing the impact of the media on life by the modern target audience of the formation of an intellectual nation.

The practical significance of this study lies in the fact that its results can be used both in further theoretical analysis of the problem and in the practice of organizing media.

Key words: intellectual nation, intangible investments, human capital, knowledge society. 


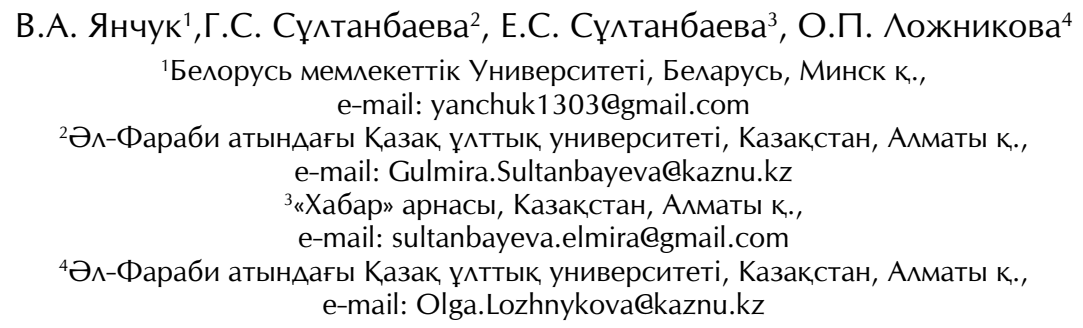

\title{
Интемлектуалдық капитал білім қоғамының негізі
}

Мақала білім қоғамының дамуы мәселелеріне арналды. «Интемлектуалдық ұлт» қалыптасуы - XXI ғасырдағы дамудың басты қайнар көзі шығармашыл аАам болып саналатын қоғамның модернизациялық жолы. "Интемлектуалдық қоғам жобасында» маңызды үш фрактор ескерілуі тиіс: жаңа шешімлер қабылдау, технологиялар мен инновациялар әзірлеу, ақпараттық революция және жастардың рухани тәрбиесі. Бүгінгі Қазақстанның әлемдік нарықта бәсекеге қабілетті мамандар даярлауда лайықты әлеуеті мол.

Мақаланың мақсаты - адамның адами қасиеттері мен рухани-адамгершілік қасиеттерге толы кәсіби маман ғана емес, сонымен қатар, адамның ең жоғары құндылығы мен негізгі капиталды анықтау.

Мақалада зияткерлік инвестициялар, материалдық емес құндылықтар, экономикалық еркіндік, саяси бостандық, бұқаралық, коммуникация және қоғамдық мүАлелер, саяси дискурс пен метафора саласында зерттеулер жүргізген көрнекті ғалымдардың еңбектеріне жүйелі және салыстырмалы талдау, сондай-ақ ұлттық қалыптастыру жолдарын талдау, талқылау және баға^ау қарастырылған. Қазақстанның әлеуеті. Жалпы аАамзаттық игіліктер мен ұлттық құндылықтарға негізделген рухани қоғам құру - әрқайсымыздың міндетіміз.

Қазақстанның зияткерлік әлеуетін арттыру үшін білім қоғамын құру қажет. Бұған ықпал ететін алғышарттар ғылыми және инновациялық әлеуеттің артуы, тұрғындар үшін білімге қол жетімділіктің артуы, азаматтар үшін ақпарат теңдігінің қол жетімАілігінің артуы және халық үшін рухани-адамгершілік құндылықтардың қол жетімділігінің артуы болып табылады.

Зерттеу жұмысында теориялық бөлімдегі мазмұнды та^дау әдісі мен анкета әдісі қолданылды. Бұл зерттеудің ғылыми жаңалығы - интелмектуалды ұлт қалыптастырудың заманауи мақсатты аудиториясының бұқаралық ақпарат құралдарының өмірге әсерін оңтайландыру бойынша ұсыныстарды әзірлеу.

Бұл зерттеудің практикалық маңыздылығы оның нәтижелерін проблеманы әрі қарай теориялық талдау кезінде де, БАҚ ұйымАастыру тәжірибесінде де қолдануға болатындығында.

Түйін сөздер: интемлектуалдық, ұлт, материалдық, емес инвестициялар, аАам капиталы, білім қоғамы.

\author{
В.А. Янчук ${ }^{1}$, Г.С. Султанбаева², Е.С. Султанбаева 3 , О.П. Аожникова ${ }^{4}$ \\ 'Белорусский государственный Университет, Беларусь, г. Минск \\ ${ }^{2,4}$ Казахский Национальный университет им. аль-Фараби, Казахстан, г. Алматы \\ ${ }^{3}$ Агентство Хабар, Казахстан, г. А^маты, \\ ${ }^{1}$ e-mail: yanchuk1303@gmail.com \\ ${ }^{2} \mathrm{e}-\mathrm{mail}$ : Gulmira.Sultanbayeva@kaznu.kz \\ ${ }^{3}$ e-mail: sultanbayeva.elmira@gmail.com \\ ${ }^{4} \mathrm{e}-\mathrm{mail}$ : Olga.Lozhnykova@kaznu.kz
}

\section{Интемлектуальный капитал как основа развития общества знаний}

Статья посвящена проблемам развития общества знания. Формирование «интемлектуальной нации» - это путь модернизации общества в XXI веке, когАа главным источником развития становится человек креативный. «Проект интелмектуальной нации» Аолжен учитывать три возможных момента: создание новых решений, технологий и инноваций; информационная революция; духовное воспитание молодежи. Сегодня у Казахстана достаточно возможностей, чтобы занять достойное место в сфрере подготовки специалистов, конкурентоспособных на мировой арене.

Цель научного исследования - анализ стратегических концептов и форм реализации отечественного модернизационного вектора «интемлектуальной нации», изучение гуманизационных аспектов информационного обеспечения общества знаний.

Авторами был проведен системный и сравнительный анализы работ выдающихся ученых, проводивших исследования в области интемлектуальных инвестиций, нематериальных ценностей, 
экономической свободы, политической свободы, массовой коммуникации и общественных интересов, политического дискурса и метафорики, а также анализ, обсуждение и оценка путей формирования национального потенциала Казахстана. Создание духовного общества, основанного на общечеловеческих благах и национальных ценностях, является обязанностью каждого из нас.

А^я повышения интемлектуального потенциала Казахстана необходимо создание общества знаний. Предпосылками, способствующими этому, считают повышение научно-инновационного потенциала, Аоступности получения знаний Аля населения, расширение информационного равенства Аля граждан, духовно-нравственных ценностей для населения.

При работе наА исследованием был использован метод контент-анализа - в теоретической части и метод анкетирования. Научная новизна настоящего исслеАования заключается в разработке рекомендаций по оптимизации воздействия СМИ на жизнь современной целевой аудитории, формирование интемлектуальной нации. Практическая значимость настоящего исследования состоит в том, что его результаты могут быть использованы как в Аальнейшем теоретическом анализе проблемы, так и на практике организации СМИ.

Ключевые слова: интемлектуальная нация, нематериальные инвестиции, человеческий капита^, общество знания.

\section{Introduction}

The strategic objective for Kazakhstan, as well as for other developing countries, is to conduct an overall modernization, in terms of which not only institutes and mechanisms of modern society, but the modern society itself will be created. Currently a new division of labour is forming in various spheres of economies from the sphere of intellectual labour, to the spheres of scientific and cultural production and service. At the same time, we are witnessing the formation of the new knowledge economy and information society. This gives crucial opportunities to Kazakhstan to enter the society of the future in economic and cultural alliance together with its partners. The establishment of "intellectual nation", a process of creative and well educated people becoming the basis of state development, is an innovative way of the society modernization in the new millennium. The definition of creativity could be derived from the self-realization of an individual, and it emphasizes spiritual wealth, individuality and individuality over tangible assets such as financial wealth. So we can assume that the diversity and richness of historical and cultural heritage from the past till modern times could become a source of future prosperity. Therefore the establishment of truly intellectual nation is one of the Kazakhstan strategic objectives of development that stand on the vectors of high-quality education and support of the younger generation.

A student expedition organized this year during the period from June 19 to July 02 within the framework of "People-to-people" campaign has first conducted the researches in Mangystau, Kyzylorda and Semipalatinsk regions. Also during the expedition an information campaign called "A letter to the village", devoted to problems of our villages and a situation of villagers, has been held.

In addition, in order to identify opinions on the possibility to create intellectual nation among Kazakhstan young people a research in focus-groups was conducted. Young people aged 18-20 from Kyzylorda, Atyrau and Almaty took part in them. An important direction of the research was to determine public opinion, necessary to develop information and communication technologies for efficient impact, aimed at enhancing intellectual potential. To investigate this issue, questionnaires were created and the work in focus groups was conducted. The results are structured in diagrams. Also a humanitarian project - "Kazakh Eli" ("Kazakh country") student scientific expedition - was performed.

New information technologies have brought major changes to the economy. Development, research and intangible investments in human capital have taken a prominent place in comparison with material investments. Therefore, economic activity is now focused on intangible components. Swiss scientists B. Carlson and G. Eliasson consider economic development a realization of the idea of new technologies (Carlsson B., Eliasson G., 2001). According to English scientist T. Stewart intellectual capital is a new source of wealth organization (Stewart T., 1991). In order to succeed in the immaterial economy, organizations and individuals should master the techniques 
that are different from their previous skills. In other words, "knowledge" has become the key word of the new economy, global hyper competition and paradigms of global management. Knowledge that can be converted into a value - this is how intellectual capital is considered by L. Edvinsson (Edvinsson L., Malone M.,2015). Clement W., Hammerer G., Aussagen Z. identify intellectual capital with all the non-monetary and non-material resources involved in the formation of an organisation's value. (Clement W., Hammerer G., Aussagen Z., 1995). Albert S. and Bradley $\mathrm{K}$. call intellectual capital "the process of turning knowledge and intangible assets into useful resources that provide competitive advantages to individuals, businesses and nations" (Albert S., Bradley K., 1996). J. Teece applies synonymous concept to intellectual capital "Knowledge Assets", emphasizing the need for an economic benefit of individual and organizational knowledge as strategic assets (Teece D.J.,2009).

In Kazakhstan, the creation of a knowledge society, its formation and transformation into the country's main value is a leading strategic goal and promising performed task of the state policy. It is proved by the fact that over the past three years, Kazakhstan is in the top four leaders in the UNESCO Education Development Index among 129 countries. One of the first projects aimed at complex research of intellectual nation formation in the field of social and political science of Kazakhstan is the project called "From an intellectual nation to the intellectual potential: development of information and communication technology impacts on the masses".

Activities carried out to determine the immediate future and implement comprehensive programs in the framework of "Intellectual Nation 2020" project are the first studies in this field. In order to analyse the factors that determine mental and intellectual capital of people, a content analysis and a factor analysis have been conducted and a political discourse of Kazakh mass media materials has been studied.

The subject of the study is Intellectual Capital as the Basis of Knowledge Society Development.

The aim of the research work is to study and determine the role and influence on the development of intellectual capital based on the implementation of the state program of the intellectual nation in Kazakhstan.

The theoretical foundations of the study include communication, management, public opinion, as well as theoretical studies in the field of communication, devoted to the problems of the information society.

The methodological foundations of the dissertation research include systemic, comparative and functional-structural examinations. (Kenzhegaraev N.D.,2012)

Object of the social process was determined as the multifaceted aspects and general characteristics of the knowledge society through the systemic method. The comparative method, which determines the general and distinctive features of events and phenomena in the life of society, revealed the dynamic development of the process of formation of a knowledge society, the methods of their impact on public consciousness, as well as the similarities and features of their application.

Analyzing the important structures of the processes of the society of employment and its functions using the functional-structural method, the authors evaluate the development processes of the intellectual society in Kazakhstan.

Sources of research. In the process of writing the material, along with the work from Kazakhstan and abroad, authors used sources that defined the concept of a knowledge society and intellectual capital.

\section{Main part}

World leading states development resulted in the establishment of post-industrial economy, and them led to the ultimate formation of the new economic models that include knowledge economy, global information systems, intellectual labour economics, and innovations economy that consist of science and the latest technologies. The foundation of these innovative models is intellectual potential. It is also the touchstone of the modern social and economic development. Interest in studying of the processes of intellectual development of the society has increased sharply in the recent years. According to Levashov V. K. "primarily this is due to the formation and establishing of knowledge society, which is a new social and economy formation whose production, distribution and effective use of scientific knowledge and technologies become the main driving force and a product". (Levashov VK.) Currently education is undergoing the process of becoming one of the leading sectors of economy. And since the most valuable people are the ones who are capable 
of making discoveries or create new development trajectories in industry, science, culture and etc., a human capital is a basis of modern economy. Therefore, the crucial undertaking of higher education is to prepare well educated and creative professionals, who can join the future workforce of Kazakhstan. Nowadays higher education of Kazakhstan is confronted with new tasks. They have been outlined by the first president of the Republic of Kazakhstan Nazarbayev N.A. in the national project "Intellectual nation - 2020: education of Kazakhs of new formation, turning Kazakhstan to the country with competitive human capital" (Bukalov C., 1995).

The main vectors of the establishment of the intellectual nation are the support of the new generation and high-quality education. Therefore, it became one of the strategic objectives of Kazakhstan development. According to the foreign experts in the field of education, Kazakh youth has a high level of intellectual potential. This was also proved by the high results in the global intellectual competitions, tests and other indicators. However, it is a challenging task to educated and nurture a future specialist and give the right support so his abilities and hidden talents can come to light. It is also important to create the right circumstances for the dexterous use of the gained knowledge.

The aims of intellectual society are to meet the demand in professionals who are equipped with new knowledge, to use the scientific achievements in certain economic sectors and to generate humanitarian values of our country. Humanitarian technologies, whose task is to manage social and humanitarian systems, take the leading position in the formation of an intellectual society citizen.

Scientific debates about the definition of "humanitarian technologies" concept have been going on for more than half a century. Researches on this topic are held in many countries around the world. Bukalov A. V., who is one of the developers of socionics, a new scientific discipline, defines humanitarian technologies as methods of education (Ostrovsky E.). Humanitarian technologist Ostrovsky gives another definition: "Humanitarian technologies are a set of carefully verified and scientifically proven methods and special techniques of indirect impact of humanitarian technologists on the society through social behaviour control". According to the Russian researcher Kurochkin, "humanitarian technologies are a set of control procedures of social and humanitarian systems that have the following characteristics: public field of application, future-oriented (strategic nature), exclusivity and optimism" (Kurochkin A.). Therefore, the search for general grounds and principles is one of the central aims of humanitarian technologies. These principles contribute to the process of understanding the framework of numerous institutional subsystems and can be a basis of action interpretation. One of the focal points of humanitarian strategies is the evolution of direct communication because they also possess a strategic nature. This strategic nature focuses on the long-term problem-solving method and, in general, is select way, which is designed for a specific problem or project unit. At Harvard University in USA the researches in the field of humanitarian initiatives - Harvard Humanitarian Initiatives - are conducted. Comprehensive researches on humanitarian technologies are conducted in Qatar. Humanitarian Research Base - http://crisismappers.net/ is an advanced information resource. 191 countries around the world are involved into this project and in 2007 a Crisis Map was developed on the basis of this project (Bounfour A., 2007). The core purpose of this project is to recognize and identify the impact of industrial technologies achievements on human and management of crisis situations in the society. It is possible to note some successful researches, conducted within the framework of the Innovation Summit for Education and Science - http://www. wise-qatar.org/ in Qatar. Studies in this field, implemented in practice, were carried out in Russia. In this regard, the study of humanitarian technologies aimed at developing intellectual capital of the nation and formation of "a citizen of intellectual society" of Kazakhstan is represented not only scientific but political task. According to Kazakhstan scientists, a comprehensive study of humanitarian technologies affecting public consciousness and results of strategic objectives should be implemented "at the present stage of formation of "a citizen of intellectual society". An urgent problem during the period of rapid development of the world's economic, social and political processes is determination of spiritual values and ideological principles of Kazakhstan society and their directing to the civilization provisions. Development of a new scientific technology in Kazakhstan, including the development of a new field - the field of humanitarian technologies that are the basis of the formation of moral values of the society, 
may be considered as a way to answer the pressing questions of our time. In general, the idea of humanitarian technology enables to consider humanities in a new light, their possible impact on the state of the society and human life. In today's world, human capital is one of the most effective factors of economic, social, cultural and political development. It became the main instrument for formation and development of innovative economy and knowledge economy as a higher stage of the development of the world economic system. The main aim of "Intellectual nation - 2020" program is the production of the most important capital and supreme value - a human, and not only a professional, but an individual, full of qualities and properties of spiritual and moral personality. (Sultanbaeva GS, Kulsarieva AT, Zhumashova JA. Volkova N.A., 2012).

The process of formation of Kazakhstan as a competitive nation results in the formation of two parallel courses of development such as activization and mobilization of intellectual capital of the state. And these development courses are intertwined with the human capital quality improvement. The research "From an intellectual nation - to the intellectual potential: development of information and communication technology impacts on the masses" discusses development of information and communication technology impact on the public as an important tool of analysis (Lukyanov D.V., 2007). It also puts in the agenda determination of immediate future and effective implementation of information and communication processes to increase the intellectual potential and formation of an intellectual nation of Kazakhstan. One of the notions that outline intellectual nation is the top priorities of industrialinnovative development of the country. Therefore it is important to develop information policy that can also make it possible to predict implementation of capacity of the country in a new direction. A step in the direction preconditions of intellectual investment in the future is also significant during the process of quality improvement of human capital. And in the context of Kazakhstan a comprehensive national program "Intellectual nation - 2020" is an essential footing of the formation of intellectual nation. It is a historical document because it identifies the crucial need for intellectual revolution as an instrument of awakening of the national potential. The term "intellectual capital" (intangible), the so-called terms of non-material sphere, is widely analysed and described. "Intangible Investment" is a term denoting investments in intangibles (Humanitarian technologies in the university educational practice: theory and design methodology: Textbook, 2007). This theory is widely discussed in scientific communities and is widely known. Therefore, justification of the theory of this problem is essential. New information technologies have made major changes in the economy (Mynbay D.). Development, research and non-material investments in human capital have taken leading position in comparison with material investments, because nowadays the economic activity is focused on non-material components. Today the term "intangible investment" is introduced again and is being discussed a lot in the economy sphere. A definition of this term is being formed and recommendations on taking into consideration intangible investments are provided. Generally, intangible values should be considered as a major component of society development and improvement of economy effectiveness (Nazarbayev N.A.).

\section{Conclusion}

In modern conditions of reforming Kazakhstan statehood and modernization of all aspects of social life, problems of development of cultural policy are actualized, which is adequate to the basic social and cultural vector of our country's development based on communicative and humanistic paradigm contributing to the strengthening of civil society. It is known that Kazakhstan is often positioned as a country with large resources and raw materials, which are regarded as a leading factor of modernization. But today this position loses its uniqueness as a number of countries have demonstrated the possibility of national modernization, when the main factors became social and cultural resources associated with the development of human capital, the ability to integrate modern technologies with the national spiritual values. Examples include Singapore, Malaysia, Turkey, China, and other countries. These aspects of modernization of Kazakhstan society remain unthought both in theoretical and applied perspective. Under these conditions the problem of analysis of modern humanitarian strategies and technologies, comprising a high resource of enhancing human capital and spiritual motivation of people to create a knowledge-based society is actual. This was the aim of the research study.

Address to the problem of intelligence and research on the formation of intellectual nation gave 
opportunities for collective conversations, interviews and public opinion development on a new content, a new form and modern image of Kazakh country. Kazakhstan society has decided to implement the process of intellectual nation formation starting with itself.

The society of spiritual values but not the material society governs in the information age. Intellectual values have now started developing in technological environments where humanities and science are the priority. Science has proposed and implemented new technologies. It became clear that any advanced technology cannot replace human consciousness, thinking and feelings. Therefore, during the development of information society human capital becomes a top priority. Adoption of multiple data streams and analysis of human intelligence is a complex process. Finding the right way and the right direction of spiritual compass of the society is the task of government and scientific community (Levashov V.K.).

In the scientific community the study of humanization began, and a new sphere, the sphere of humanitarian technologies, appeared. Consideration of possibilities of humanitarian technologies and usage of their results in the formation of an intellectual nation is now a civic duty. These tasks impose on the communities with advanced thinking requirements on the formation of an intelligent citizen, enhancing his participation in decision-making process, increasing confidence of an individual and society to each other. Conducted scientific research has clearly defined the vector of development and formation of intellectual nation. First, these are socio-political and economic reforms. Also the formation of new views on spiritual values is the food for public thought. In order to study the technology of intellectual nation formation under the state program "Intellectual potential of citizens" the Department of press and electronic mass media of Al-Farabi Kazakh National University conducted an expert survey. The object of the research is the development of human technologies in shaping public consciousness of a citizen of the intellectual society.

The factors affecting the development of nation's intellectual capital and formation of spiritual and moral values, ethical standards as the main indicator of the development of education and science have been analysed (Zhuravlev V.A.,2009). Mechanisms for attracting investments to increase intellectual potential have been studied. Global best practice to develop humanitarian analysis has been analyzed. On the basis of these analyzes the ways to improve intellectual potential of Kazakhstan were discussed and identified. Humanitarian basis on the problems of Kazakhstan's intellectual capital has been prepared.

A humanitarian expertise, which identifies the factors influencing the development of intellectual capital and the formation of spiritual and moral values as well as ethical standards, has been conducted. Humanitarian studies considering mechanisms of the formation of social consciousness of a citizen of intellectual society have been conducted. Also humanitarian analysis aimed at the development of mental and intellectual capital of the population has been carried out. In order to develop humanitarian technologies aimed at formation of knowledgebased society and social planning, public opinion was studied. Corporate, communicative, political and cultural strategies have been developed.

\section{References}

Albert S., Bradley K. The Impact of Intellectual Capital / Open University Business School Working Paper. 1996. - №15. P. 98-101.

Bukalov C. About place of socionika in a number of other systems. SmiPL. 1995; 2: 56-58.

Bounfour A. University of Marne La Valle, France Assessing Performance of European Innovation Systems: An intellectual Capital Indexes Perspective.

Carlsson B., Eliasson G. Industrial Dynamics and Endogenous Growth. KTH. - Stockholm: Sweden, 2001. - 24 p.

Clement W., Hammerer G., Aussagen Z. Zur österreichischen Hartwäh-rungspolitik. - Industriewiss. Inst., 1995.

Edvinsson L., Malone M. Intellectual capital. Determining the true value of the company [Electronic resource] URL: http://iirmp.narod.ru/books/ inozemcev/ page_1429.html (date accessed: 16.05.2015)

Humanitarian technologies in university educational practice: theory and design methodology: Textbook. St. Petersburg. 2007:198.

Kenzhegaraev N.D. Basic methodological principles of formation of intellectual personality based on the concept of A. Kunanbaeva "Complete Person". Materials of II International Scientific Conference / Pedagogy: tradition and innovation. Chelyabinsk, Russia, 2012: 96-98. 
Kurochkin A. Humanities technology: the problem of choosing the methodological foundations. www.gtmarket.ru/laboratory/ expertize/2006/725

Levashov V.K. Intellektual'nyy potentsial obshchestva: sotsiologicheskiye issledovaniya i prognozirovaniye [Intellectual potential of society: sociological research and forecasting] http://www.gtmarket.ru/ratings/legatum-prosperity-index/info.

Lukyanov D.V. Istoriograficheskoye znaniye i gumanitarnyye tekhnologii sovremennosti. Kommunikativnyye strategii kul'tury i gumanitarnyye tekhnologii. Nauchno-metodicheskiye materialy. [Historiographical knowledge and modern technologies of the humanities. Communicative strategies of culture and humanitarian technologies. Scientific and methodological materials.] - St. Petersburg, 2007. - 79 p.

Mynbay D. The Laws of History www.centrasia.ru/newsA.php

Nazarbayev N.A. Sotsial'no-ekonomicheskaya modernizatsiya- glavnyy vektor razvitiya Kazakhstana [Socio-economic modernization is the main vector of development of Kazakhstan] // www.akorda.kz

Ostrovsky E. Advertising as a tool for high humanitarian technologies. www.rae.ru

Stewart T.A. Intellectual Capital. The New Wealth of Organizations. - N.Y. - L., Doubleday / Currency, 1997. Copyright T.A.Stewart, 1997

Sultanbaeva G.S., Kulsarieva A.T., Zhumashova Zh.A. Ot intellektual'noy natsii - k intellektual'nomu potentsialu. Kollektivnaya monografiya. [From intellectual nation to intellectual potential. Collective monograph.] - Almaty: IE Volkova N.A., 2012.-9 p.

Teece D.J. Dynamic capabilities and strategic management $\backslash$ Oxford University Press.2009

Zhuravlev V.A. Intellektual'nyy potentsial kreativnogo obshchestva - elementy i kharakteristika // Kreativnaya ekonomika. [Intellectual potential of a creative society - elements and characteristics // Creative Economy.] - 2009. — № 8 (32). - C. 3-14. 